\title{
PROGRESS IN THE AMENDMENT OF SECTION 6oa OF THE BANKRUPTCY ACT
}

\author{
MrLton P. Kupfer* \\ I \\ INTRODUCTORY NOTE
}

Much has been well written by many upon the deficiencies of Section 6oa of the Bankruptcy Act in its present form, ${ }^{1}$ the unfortunate consequences of its language, and the efforts that have been made to cure, or in any event to ameliorate, them. The literature on the subject is so ample ${ }^{2}$ that it is not without some hesitancy that one brings oneself to re-enter the field. The justifications for the present contribution are, first, that this symposium would not be complete without some reference to this important and still vexing subject, and second, that none of the recent writings upon it brings its status up to date.

The foregoing statement of its raison d'etre will indicate the scope of this article. Its purpose is distinctly not to reactivate all of the controversies that have raged about Section 6oa in its present form, leaving it, if not pretty "sick," as one set of authors has trenchantly observed, ${ }^{3}$ at least with a fairly discredited corpus. More

- A.B. rgr6, Columbia University; LL.B. I920, Columbia University Law School. Editor, Columbia Law Review, I916-1920. Member of the New York and Federal bars since 1920. Author, articles on bankruptcy and creditors' rights; co-author, earlier editions of The Selected Digest of New York Statute Law. Chairman, Committee on Bankruptcy and Corporate Reorganizations of the Association of the Bar of the City of New York. Member of the Bankruptcy Committce of the New York County Lawyers Association. Councilman, Section of Corporation, Banking and Mercantile Law of the American Bar Association. Member, National Bankruptcy Conference. Member of Selective Service Board of Appeal (New York), r940-47, r948- General Counsel, National Conference of Commercial Receivable Companies, Inc.

${ }^{1} 52$ STAT. 869 (1938), II U. S. C. A. $\$ 96 a$ (1947).

2 MacLachlan, Defining a Preference in Bankraptcy, 6o Harv. L. Rev. 233 (1946); Hanna, Some Unsolved Problems under Section 6oa of the Bankruptcy Act, 43 CoL. L. REv. 58 (1943); Hanna, Foreword to Koessler, Assignment of Accounts Receivable: Confusion of the Present Law, the Impact of the Bankruptcy Act, and the Need for Uniform Legislation, 33 Cal.1F. L. Rev. 40 (1945); Hanna, Preferences in Bankruptcy, I5 U. of CHI. L. Rev. 3 II (1948); Ireton, A Proposal to Amend Section 6oa of the Bankruptcy Act, A6 AM. BANkr. REv. 257, 287 (I947); Keeffe,Kelly, and Lewis Sick Sixty; A Proposed Revision of Section 6oa of the Bankrupecy Act, 33 ConN. L. Q. 99 (1947); Kupfer and Livingston, Corn Exchange National Bank and Trust Company v. Klateder Revisited: The Aftermath of Its Implications, 32 VA. L. REv. 910 (I946); Kupfer and Livingston, Corn Exchange National Bank and Trust Company v. Klauder Revisited: A Supplemental Note, 33 VA. L. Rev. I (1947); Lowenstein, Assignments of ACcounts Receivable and the Bankruptcy Act, I RutGers U. L. Rev. I (r947); Oglebay, Proposed Revision of Section 6oa of the Bankruptcy Act: A Step Backward, 51 CoM. L. J. 263 (I946); Martin, Substantive Regulation of Security Devices Under the Bankruptcy Power, 48 CoL. L. Rev. 62 (1948); Moore and Tone, Proposed Bankruptcy Amendments: Improvement or Retrogression?, 57 YAL.E L. J. 683, 686-692 (1948); McGowan, Trust Receipts Under Section 6oa, Credit and Financial Management, February, I948, p. 4 .

${ }^{3}$ The authors (Professor Keeffe and Messrs. Kelly and Lewis) of the article in the Cornell Law Quarterly (supra note 2) manifested alliterative inspiration and also hit the nail on the head when they entitled their article "Sick Sixty." 
than plenty has been said on that subject, leaving it to the student to take his choice. For the businessman, in addition, the exercise of the choice involves a real financial hazard.

For present purposes, it will be sufficient to observe that, of the many experts who have written upon Section 6oa, the great majority, including the principal author of the present language himself, ${ }^{4}$ feel that it should be amended. ${ }^{5}$ Among them, there is general, although not complete, agreement as to what the amendment should provide. Identical bills ${ }^{6}$ are currently pending in both houses of Congress to effectuate such an amendment.

The purposes of this article will, therefore, be:

I. To set forth the present status of the amendatory bills; ${ }^{7}$

2. To deal with certain supplemental suggestions that have been made with respect to their language; 8

3. To discuss amendments to other sections of the Bankruptcy Act that the proposed amendment to Section 60 a has suggested $;^{9}$

4. Briefly to discuss a separate proposal, providing, in effect, for the compulsory national recordation of the assignment of accounts receivable, ${ }^{10}$ which has been injected into the Section 6oa matter; and, finally,

5. To state certain conclusions that seem valid in the light of all of the foregoing. ${ }^{11}$

II

Present Status of the Amendatory Bill

A

As has been pointed out by the author in a prior article, ${ }^{12}$ the present bills ${ }^{13}$ resulted from a study made by a Special Committee of the American Bar Associa-

"Professor MacLachlan, in his article, "Defining a Preference in Bankruptcy," supra note 2, passim.

"With the exceptions stated in this footnote, all of the articles listed in note 2 supra endorse the amendment of Section $60 a$ along the lines hereinafter discussed. "Sick Sixty" qualifies its endorsement with two suggestions, which are also hereinafter developed. The only articles opposing the amendment outright are those of Mr. Oglebay, and of Professor Moore and Mr. Tone. Professor Martin, recognizing the need for some amendment, would lay the whole matter over for further study.

'H. R. 2412 and S. 826, 8oth Cong., Ist Sess. (1947).

${ }^{7}$ Section II infra.

${ }^{8}$ Section III infra.

${ }^{10}$ Section $V$ infra.

${ }^{9}$ Section IV infra.

11 Section V infra.

${ }^{12}$ Kupfer and Livingston, Corn Exchange National Bank and Trust Company v. Klauder Revisited: The Aftermath of Its Implications, 32 VA. L. Rev. 910 (1946); Kupfer and Livingston, Corn Exchange National Bank and Trust Company v. Klauder Revisited: A Supplemental Note, 33 VA. L. REv. I (1947).

${ }^{13}$ The text of the bills follows (existing law retained is indicated by ordinary type; existing law omitted is enclosed in brackets; and new matter is italicized):

"6oa. (I) A preference is a transfer, as defined in this Act, of any of the property of a debtor to or for the benefit of a creditor for or on account of an antecedent debt, made or suffered by such debtor while insolvent and within four months before the filing by or against him of the [petition in bankruptcy, or of the] original petition initiating a proceeding under [chapter X, XI, XII or XIII of] this Act, the effect of which transfer will be to enable such creditor to obtain a greater percentage of his debt than some other creditor of the same class [.] : Provided, however, That this section shall have no application to proceedings under chapter IX of this Act.

"(2) For the purposes of subdivisions (a) and (b) of this section, and subject to the provisions of paragraph (3), a transfer shall be deemed to have been made or suffered at the time when it became so far perfected that no [bona fide purchaser from the debtor and no] creditor obtaining under appli- 
tion on the subject, ${ }^{14}$ necessitated-or, in any event, occasioned-by the ruling of the United States Supreme Court in Corn Exchange National Bank \&. Trust Company $v$. Klauder, ${ }^{15}$ as extended by the opinion in In re Vardaman Shoe Company. ${ }^{16}$

Unfortunately, the latter decision was not, even if it could have been, appealed. The balance was to some extent redressed by the opinion of the Third Circuit Court of Appeals in In re Rosen. ${ }^{17}$ The Rosen opinion is exceptionally keen and well written, but, again unhappily, the opportunity specifically to repudiate the Vardaman case ${ }^{18}$ was there not availed of, and occasion for further judicial expression on the subject has not subsequently arisen. Eight of the ten circuits still remain to be heard from. Indeed, it is not at all certain that, under the existing language of the section, judicial declaration could do very much to cure poor "Sick Sixty," anyway.

cable law by legal or equitable proceedings on a simple contract a lien on such property without a special priority (whether or not such a creditor exists), could [thereafter have acquired] acquire, after such perfection, any rights in the property so transferred superior to the rights of the transferce therein, and [,] if such transfer is not so perfected prior to the filing of the [petition in bankruptcy or of the] original petition initiating a proceeding under [chapter X, XI, XII or XIII of] this Act, it shall be decmed to have been made immediately before [bankruptcy.] the filing of such original petition: Provided, however, That where teal property is transferred for or on account of an antecedent debt, the transfer shall bie deemed to have been made at the time when it became so far perfected that no bona fide purchaser from the debtor could acquire, after such perfection, any rights in the property so transferred superior to the rights of the transferee therein.

"(3) A transfer, wholly or in part, for or on account of a new and contemporaneots consideration shall, to the extent of such consideration and interest thereon and the other obligations of the transferor connected therewith, be deemed to be made or suffered at the time of the transfer, unless the applicable law requires the transfer to be perfected by recording, delivery or otherwise, in order that no creditor described in paragraph (2) could acquire, after stch perfection, any rights in the property so transferred superior to the rights of the transferee therein. A transfer to secure a future loan, if such loan is actually made, or a transfer which becomes security for a future loan, shall have the same effect as a transfer for or on account of a new and contemporaneous consideration. If any requirement specified in this paragraph (3) exists, the time of the transfer shall be determined by the following rules:

"I. Where (A) the applicable law specifies a stated period of time of not more than thirty days after the transfer within which recording, delivery, or some other act is required, and compliance therewith is had within such stated period of time; or where $(B)$ the applicable law specifies no stich stated period of time or where such stated period of time is more than thirty days, and compliance therewith is had" within thirty days after the transfer, the transfer shall be deemed to be made or suffered at the time of the transfer.

"II. Where compliance with the law applicable to the transfer is not had in accordance witl the provisions of subparagraph I, the transfer shall be deemed to be made or suffered at the time of compliance therewith, and if such compliance is not had prior to the filing of the original petition initiating a proceeding under this Act, such transfer shall be deemed to have been made or suffered immediately before she filing of such original petition."

The bills were endorsed for congressional enactment by the House of Delegates of the American Bar Association at its Adantic City convention in October, 1946, and they have also, with the addition of a single sentence, to be hereafter discussed, been endorsed by the National Bankruptcy Conference.

14 This committee was appointed by the Section of Corporation, Banking and Mercantile Law of the American Bar Association, at its Cincinnati convention in December, 1945. It originally consisted of Homer J. Livingston, chairman; Professor John Hanna of the Columbia Law School; J. Francis Ireton; Milton P. Kupfer; and W. Leslie Miller. In 1946, Professor James A. MacLachlan of the Harvard Law School replaced Mr. Miller, who has since died. The personnel of the committee has otherwise remained unchanged. Mr. Homer Livingston and the author of this article have been its successive chairmen.

${ }^{15} 318$ U. S. 434 (1943).

${ }_{17} 157$ F. $2 d 997$ (C. C. A. 3 d 1946).

${ }^{28}$ In their recent article (supra note 2) Messrs. Moore and Tone observe that the "Vardaman case was discredited subsilentio in In re Rosen"-a conclusion to which Judge Goodrich's opinion lends considerable support. 
However all that may be, the industrial and commercial community cannot wait upon the vagaries of litigations or the inability of lawyers, even of specialists in the field, to advise them of the impact of the section upon almost every type of security in common employment. And in this connection, the hazard, potential if not actual, exists not merely in the accounts-receivable field, wherein the Klauder case itself arose, but, even more importantly from the standpoint of commercial conse- quence, in the fields of trust receipts, conditional sales agreements for resale, factor's liens, chattel mortgages on merchandise stocks, etc.

In his article in the American Bankruptcy Review, ${ }^{19} \mathrm{Mr}$. Ireton, with ample citation of authority, persuasively argues that all of the last-mentioned security devices, even if acquired in good faith and for a present consideration, are invalidated as against a trustee in bankruptcy by the present language of Section 6oa. On the other hand, in his article, ${ }^{20} \mathrm{Mr}$. McGowan, an equally authoritative expert, ${ }^{21}$ stating reasons of equal cogency, concludes that "trust receipt transactions when handled properly are not preferences within the meaning of $\$ 60(a) .22$

In any event, the fact that such differences of opinion exist with respect to such a useful and accepted security device strongly emphasizes the need of amendment. As Mr. McGowan states at the end of his article, the difference

cannot but have an effect upon the ability of small businessmen to obtain the credit they need and could obtain if such doubts did not exist.

Competition by dealers and merchants is one means of keeping prices down. The more people who can obtain goods to sell in competition with others, the less chance there is of prices moving upward. Congress should not delay amendment of Section 6o(a) so as to resolve all doubt as to the effectiveness of the security devices by which honest men with limited resources obtain credit from lenders who are satisfied as to the borrowers' honesty but only desire to be protected against other creditors in the event that bankruptcy or insolvency occurs. ${ }^{23}$

${ }^{20}$ Ireton, A Proposal to Amend Section 60a of the Bankruptcy Act, A6 Corp. Reorg. ANd Am. Bankr. REv. 257, 263-264 (1947).

${ }^{20}$ McGowan, Trust Receipts Under Section 6oa, Credit and Financial Management, February, I948, p. 4 .

${ }^{21}$ Mr. MeGowan is the author of Trust Receipts: The Variations in Their Legal Status, published by the Ronald Press, r947.

${ }^{22}$ In an unreported case handed down on February 19, 1948 (Matter of Wallace: Petition of Commercial Credit Company, D. Md.-In Bankruptcy No. 9974), Referee Kach of Baltimore agrees with Mr. McGowan's conclusion. Since the opinion was handed down in approval of a compromise between the trust receipt holder and the trustee in bankruptcy, it will, of course, not be reviewed. The essential rationale of Referee Kach's opinion is contained in the following portions of his opinion:

"The clearly disclosed legislative intent of the Uniform Trust Receipts Act is to give those persons who comply therewith priority against all but an actual bona fide purchaser. These two purposes are accomplished and can only be accomplished by according its lienee priority over a subsequent bankruptcy trustee of its lienor. Any other holding would be such a departure from the theory and effect of every Maryland recording law as not to be presumed when, as here, un-stated, and would render the recording of the Uniform Trust Receipts Act worthless in perhaps its most important practical application....

"The 'mischief to be corrected' in the preparation of the Uniform Trust Receipts Act, was the virtual impossibility of keeping pledged merchandise sufficiently described to meet the demands of the other recording laws; 'the end to be attained' was to thereby accord priority to those who complied with its provisions. These objectives are to be respected and observed rather than an interpretation of $60 \mathrm{a}$ that would destroy every lien in bankruptcy as all yield to the creditor claim of the state for taxes."

${ }^{25}$ McGowan, supra note 20 , at 21 . 
The objects of the amendment, as developed by the Committee of the American Bar Association and approved, upon the recommendation of its Section of Corporation, Banking and Mercantile Law, by its House of Delegates, ${ }^{24}$ are:

r. To eliminate the evil of allowing a trustee in bankruptcy, for the purpose of timing his status for preference purposes, to take the position of a potential bona fide purchaser, and to restore him to the position of a potential holder of a lien by legal proceedings, in harmony with his functions under the Bankruptcy Act.

Creditors are the claimants in bankruptcy, and it was felt that they certainly could have no legitimate complaint when they are allowed all of the assets that they might have reached, irrespective of actual notice and other bars against general creditors, if they had taken advantage of every remedy that they might conceivably have invoked under applicable state laws.

2. In effectuation of the policy declared in ( $I$ ), to provide that no transfer made in good faith, for a new and present consideration, shall constitute a preference to the extent of such consideration, if the provisions of applicable state law governing the perfection of such transfer are complied with, with an appropriately rigid time-limitation ( 30 days) for such perfection if such time is not itself prescribed by the applicable state law, or if a longer one is so prescribed.

In the bills, the protection accorded transfers is definitely restricted to those made for a "new and contemporaneous consideration." Since such transfers add to the debtor's estate, they should not be subject to attack by the trustee under any hypothetical test unless there are definite state restrictions for recordation or other perfection, and these requirements have not been complied with. For example, the mere fact that a tort claimant, a distraining landlord, or a garnishee might have come in ahead of a transferee for value and in good faith should not be permitted to add to the assets of the bankrupt estate, to the prejudicial expense of the transferee, if the latter has done everything necessary under state laws.

. 3. While accomplishing the purposes set forth in ( $\mathrm{r}$ ) and (2), to retain unimpaired the basic objects of the 1938 amendment, which were to eliminate the "relation back" doctrine of Sexton v. Kessler ${ }^{25}$ and the "pocket lien" doctrine of such cases as Carey v. Donohue, ${ }^{26}$ Bailey v. Baker Ice Machine Co., ${ }^{27}$ and Martin v. Commercial National Bank. ${ }^{28}$

\section{C}

The bills, which, as above noted, are identical, were introduced in the Senate by Senator Ferguson as S. 826 on March 7, 1947, and, in the House by Representative Chauncey W. Reed as H. R. 24I2 on March 6, 1947.

In both bodies, they came under the jurisdiction of the respective Judiciary Committees. In the Senate, they were referred to a subcommittee consisting of

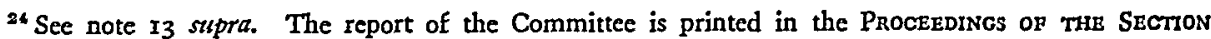
of Corporation, Banking and Mercantule Law ig6-200 (1946-r947).

${ }^{35} 225$ U. S. 90 (1912).

$2 \pi 239$ U. S. 268 (1915).

${ }^{20} 240$ U. S. $43^{\circ}$ (1916).

28 U. S. 513 (1918).
} 
Senator Ferguson of Michigan and Senator Pat McCarran of Nevada, and, in the House, to the standing Subcommittee on Bankruptcy of the Judiciary Committee. This subcommittee consists of:

Chauncey W. Reed of West Chicago, Illinois, Chairman

John W. Gwynne of Waterloo, Iowa

Edward J. Devitt of St. Paul, Minnesota

William M. McCulloch of Piqua, Ohio

Sam Hobbs of Selma, Alabama

Martin Gorski of Chicago, Illinois

Estes Kefauver of Chattanooga, Tennessee

The opinion of the Attorney General has been obtained upon the bills, and, while the contents of the opinion are not a public record, it can fairly be assumed that it does not disapprove them upon any constitutional ground. ${ }^{29}$

The demand for enactment of the amendment is insistent. It has manifested itself in a number of approving actions by the following disinterested and interested groups, all of which unconditionally support its passage:

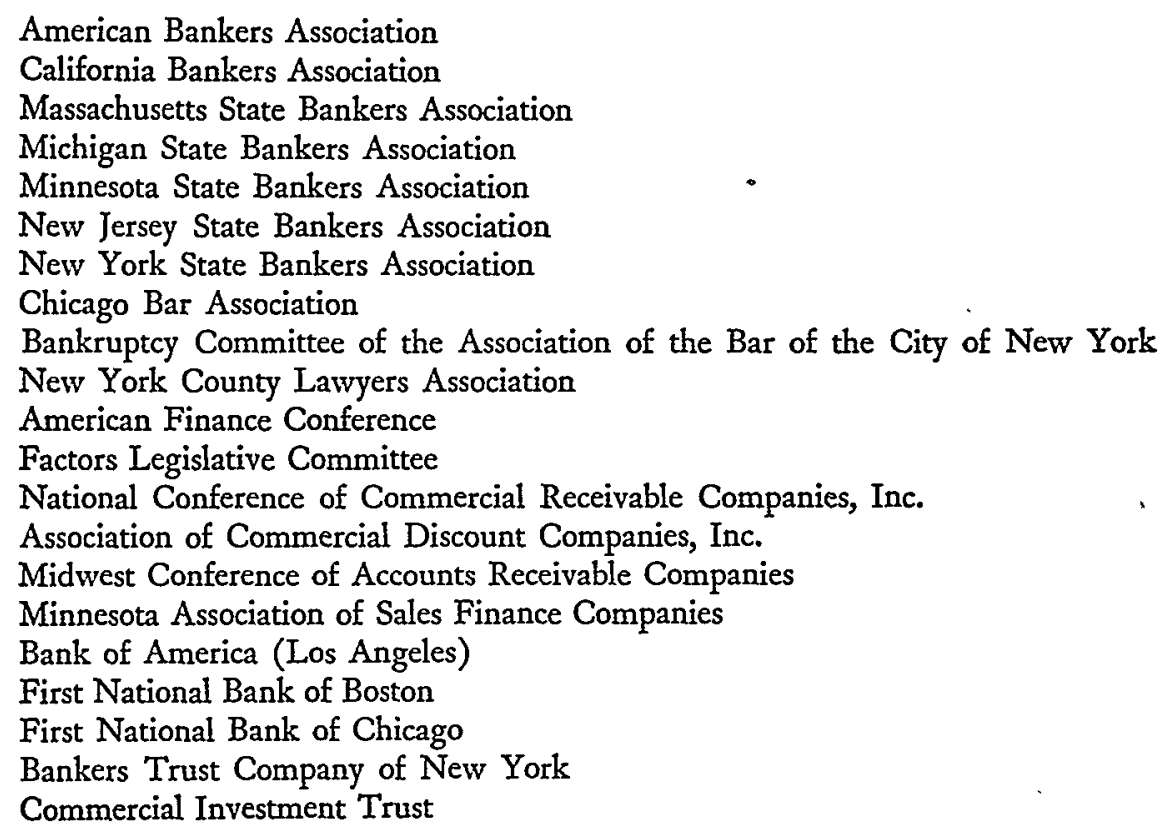

The names of these groups indicate the variety of business organizations, many of them highly competitive among themselves, to which the amendment appeals.

The National Association of Credit Men also approves it, but conditions its support upon the simultaneous enactment of a bill providing, in effect, for the recorda-

"As Professor Martin well points out in his article, supra note 2, at 70-76, the bills could go much farther than they do and still not be objectionable under the Fifth and Tenth Amendments to the Constitution. That they are within the general bankruptcy powers of the Congress is too obvious to require discussion. 
tion, on the national level, of the assignment of accounts receivable, hereinafter discussed. ${ }^{30}$ The Commercial Law League of America disapproved the amendment.

\section{D}

The bills received congressional consideration at the regular 1948 session. The Senate Subcommittee held a hearing on S. 826 on March 30 . The full Judiciary Committee reported it favorably to the Senate on June $I_{9}{ }^{31}$ and it passed that body unanimously, prior to the adjournment of the regular session. The report of the Senate Judiciary Committee stated the purpose of the bill to be:

to clarify the provisions of section 60(a) of the Bankruptcy Act and remove certain doubts that now exist among banks, factors, and other extenders of credit upon the validity of security taken in good faith and for present consideration. The present language of the act tends to impede and choke the flow of credit, principally to smallbusiness men, at a time when it should be promoted. The doubts which exist are caused by the confusion now existing in the law by reason of certain court decisions.

Then, after stating the history of Section 6oa, and analyzing the confusions created by the conflicting decisions interpreting the 1937 amendment, the report proceeded:

The resultant confusion has cast grave doubt upon the validity of normal business security, not merely in the field of accounts receivable, but, even more importantly, in the areas covered by trust receipts, factors liens, oil leases, cattle loans, airplane-equipment financing, chattel mortgages, conditional sales agreements for resale, etc. Indeed, a bank officer, who appeared as one of the witnesses at the subcommittee hearing, testified that the situation had come to such a pass that his instiuion was compelled to regard all such types of transaction as unsecured loans, and to rule on them, as to the terms upon which his bank was willing to enter into them, accordingly.

The report concluded:

It appears that the enactment of this bill is necessary, and will facilitate the extension of secured credit, primarily to small business-men upon fair and reasonable terms with fair and reasonable protection to the institution extending the credit.

In the House, the Bankruptcy Subcommittee conducted a hearing upon the companion bill, H. R. 24I2, on May 7. Shortly prior to the adjournment of the regular session, the Subcommittee reported its inability to reach a final conclusion upon the bill, and, accordingly, no final action was taken upon it.

Because of the extremely short duration of the special session and the political controversies that it generated, it was confined strictly to a consideration of the subject matters of the President's call. Accordingly, no action was taken upon the bill at the special session. ${ }^{32}$

\footnotetext{
${ }^{30}$ Section V infra.

${ }^{31}$ SEN. Rep. No. $15 I_{4}$ (To accompany S. 826), 8oth Cong., 2d Sess. (1948).

32 This manuscript is being sent to the printer on September 15, 1948 .
} 
III

\section{Supplemental Suggestions with Respect to the Language of the Bills}

A

While the sponsors of the amendment believe that it accomplishes its objectives within the limits of perhaps none-too-brief language, the last thing that they would claim for the amendment is perfection in attainiment, let alone in the language itself. And, even were they so rash, they would perforce know better, not only (I) because of the complexity of the subject matter, but also (2) because of their realization that, in the hammering out of the amendment, which consumed several years of study, drafting, and discussion, there necessarily had to be considerable give and take in reconciling the reasonable vindication of the position of the secured creditor, on the one hand, with the retention, without backsliding, of the essential elements of the rights of the trustee in bankruptcy, as representative of unsecured creditors, on the other. Its sponsors, therefore, invited criticism and suggestions, and, of the number of those received, two seemed of sufficient importance to justify recommendation for their insertion.

Many others have received consideration, and the ultimate determination not to press them was not due to any lack of appreciation of their value; it was largely due to the feeling, in the case of proposals which had not been theretofore considered, that they would over-complicate language which, in the necessary compromises, had become none too simple at best, or in other cases that they would reopen areas of dispute that either did not go to the essence or had been laid at rest.

\section{B}

To illustrate the fallibility which attends all endeavors such as this one, it was discovered that, although, in the framing of subdivision (2), Carey v. Donohue and other like cases ${ }^{33}$ had been specifically outlawed, subdivision (3) did not contain a specific provision to the same effect. The omission was, of course, inadvertent, and, considering the objectives of the amendment as a whole, would probably have been readily enough supplied by judicial interpretation. However, since this is not always a certain reliance, it was decided to cure the defect by inserting the phrase "or purchaser of real property" after the word "creditor" and before the phrase "described in paragraph (2)" in the first sentence of paragraph (3).

\section{C}

Another, and much more controversial, suggestion related to the language of the first sentence of paragraph (2). Several keen students of the subject ${ }^{34}$ pointed out that the purpose of the amendment would be better subserved by the reversal of the position of the qualifying phrases "after such perfection" and "under appli-

\footnotetext{
${ }^{33}$ See notes 26,27 , and 28 supra.

34 Among others, Mr. Walter D. Malcolm of the Boston bar, and Messrs. Holten, Dorsey, Colman, Barker, Scott, and Barber of the Minneapolis bar.
} 
cable law," and the addition of the word "thereby" in the first portion of paragraph (2), so that it would read as follows:

(2) For the purposes of subdivisions a and b of this section, and subject to the provisions of paragraph (3), a transfer shall be deemed to have been made or suffered at the time when it became so far perfected that no creditor obtaining after such perfection by legal or equitable proceedings on a simple contract a lien on such property without a special priority (whether or not such a creditor exists), could acquire thereby under applicable law, any rights in the property so transferred superior to the rights of the transferee therein, ....

They pointed out that the underlying purpose of the clause was to base the definition of a "transfer" upon a standard of reaching a certain degree of perfection; that the degree of perfection was, in turn, defined so that the position of the transferee could not be defeated by a certain type of lien-creditor; and that painstaking care had been taken to define the type of lien-creditor as one obtaining a lien by legal or equitable proceedings on a simple contract, and one without special priority.

It was observed that it was equally important to be specific in stating the time of obtaining of the lien, in further qualifying such lien-creditor, and that the time qualification for obtaining the lien should be after the perfection because, if it were not so limited, the time of obtaining might be before the perfection, and it would be difficult to see how a "transfer" could, in many cases, defeat a prior lien.

With respect to the addition of the word "thereby," is was urged that it should be made certain that the paragraph defines, not only the type of creditor who would be strong enough to defeat the transferee, but also the type of possible action by that creditor which would be taken into account in defeating the transferee. Adding "thereby" after "could acquire" defines that action as the mere obtaining of the lien, thus avoiding a result such as that reached in the Vardaman case, in which the court did not restrict itself to a hypothetical bona fide purchase, but went further and based its decision on the possibility that a hypothetical bona fide purchaser could acquire superior rights, not by the purchase alone, but by the subsequent act of collecting the account receivable. ${ }^{35}$

ss The Vardaman case rested upon the application to-or superimposition upon-Section 60a, in its present form, of the provisions of Section I73(b) of the RESTATEMENT of THE LAW OF ConTRACTs, which has become generally known as the "four horsemen." Of course, none of the "four horsemen" was actually present in the Vardaman case. Section $\mathrm{r} 73$ of the Restatement provides as follows: "Priorities Between Successive Assignments of the Same Right.

"Where the obligee or an assignee makes two or more successive assignments of the same right, each of which would have been effective if it were the only assignment, the respective rights of the several assignees are determined by the following rules:

"(b) Any assignee who purchases his assignment for value in good faith without notice of a prior assignment, and who obtains

(i) payment or satisfaction of the obligor's duty, or

(ii) judgment against the obligor, or

(iii) a new contract with the obligor by means of a novation, or

(iv) delivery of a tangible token or writing, surrender of which is required by the obligor's contract for its enforcement,

can retain any performance so received and can enforce any judgment or novation so acquired, and, if he has obtained a token or writing as stated in subclause (iv), can enforce against the obligor the assigned right ..." 
On the other side, Professor MacLachlan, who certainly is in a position to speak with authority, pointed out that, while he had no sympathy with preserving the doctrine of the Vardaman case, he could not go along with the overruling of so much of the Klauder doctrine as still remains analogically applicable to the position of a trustee in bankruptcy as a hypothetical lien creditor, which the amendment, of course, preserves. Accordingly, he suggested that both points of view could, as a practical matter, be met by inserting, at the end of subdivision (2), the following sentence:

The rights that such a lien creditor or bona fide purchaser could acquire shall include the rights acquired by the mere fact of obtaining such a lien or making such a purchase, and any further rights that might be obtained by recording any document, or giving notice to any person, or taking any step wholly within the control of such a lien holder or purchaser, with or without the aid of ministerial action by public officials, but such creditor's or purchaser's rights shall exclude those acquired by any acts or transactions subsequent to his obtaining such a lien or making such a purchase which require the agreement or concurrence of any third party, or which require any further judicial ruling. ${ }^{36}$

$\mathrm{D}$

The article so keenly entitled "Sick Sixty"37 represents a year's study of the section, conducted at the Cornell University Law School under the supervision of Professor Keeffe. As a result of this study, Professor Keeffe and his students approved the section with two additional suggestions. ${ }^{38}$

${ }^{\text {so }}$ Professor MacLachlan explains the purpose and effect of this language as follows (Committee Print of the Drafting Committee of the National Bankruptcy Conference, dated February 14, I948, page 21):

"Adequate protection of a bankrupt estate suggests that a transfer to be valid against the trustee should be so far perfected that no holder of a lien by legal or equitable proceedings could acquire rights superior to the transferee merely by recording or giving notice or taking any steps solely within his control. The fact, however, that such a hypothetical lien holder might invalidate the transfer by getting a judgment in his favor, or getting payment or a new promise from a third party should be insufficient to allow the trustee in bankruptcy to prevail. To codify this distinction the proposed amendment adds what is above set forth as the last sentence in paragraph $60 \mathrm{a}(2)$. This endeavors to spell out on a rational and practical basis what subsequent action by the lien holder shall be included and what shall be excluded in acquiring the rights against which the validity of a preferential transfer is measured. Since under H. R. 2412 real estate transfers are still to be tested with reference to the rights of a hypothetical bona fide purchaser, the newly added language is also applied to such purchasers. Thus, for example, in a jurisdiction where, as between two bona fide purchasers of real estate, the first to record his conveyance prevails, the trustee in bankruptcy will be able to claim the rights a hypothetical bona fide purchaser might acquire through following his purchase by a record of his conveyance, and, consequently, an alleged preferential transfer of real estate will not be deemed to be made until it is recorded. The proposed language will, however, exclude the possibility that the doctrine of the Vardaman Shoe case or any analogous doctrine be invoked to invalidate transactions by reference to unlimited and indeterminable hypothetical acts of hypothetical purchasers or creditors."

The National Bankruptcy Conference also approves this language, and, with its addition, has endorsed the amendment as a whole. Its Drafting Committee would also add a new Section 7oi providing, in effect, for the compulsory national recordation of the assignment of accounts receivable. This proposal will be discussed in Section $\mathrm{V}$ infra.

${ }^{37}$ Keeffe, Kelly and Lewis, Sick Sixty: A Proposed Revision of Section 6oa of the Bankruptcy Act, 33 CorN. L. Q. 99 (1947).

${ }^{38}$ Although these suggestions have not been considered by the committee, as such, they have been canvassed among its membership. It is therefore believed that the immediately succeeding portion of the text represents the views of the individual members of the committee, but the contents thereof should be regarded as made solely on the author's responsibility. 
The first suggestion is that a proviso be inserted in paragraph (2), depriving "any equitable lienor" of its protection. Apart from the possible unfairnesses that the authors themselves frankly recognize, ${ }^{39}$ the insertion would, for the following three reasons, hardly seem sound:

I. The concept of "equitable lien" is so indefinite and obscure that its insertion into the statute might well lead us into difficulties of interpretation that are as bad as, or even worse than, those which now confront us. At the very least, the term is not self-defining and there are many different concepts as to the area that it covers; and

2. Its insertion would be inconsistent with the basic purpose of the amendment;

3. It would involve paragraph (3) of the amendment in almost irreconcilable conflict with paragraph (2).

The second suggestion of the "Sick Sixty" article is the insertion, at the end of paragraph (2), of the following proviso:

Provided, further, that for the purposes of this section, applicable law shall be construed to mean the statutes of a state and the common law of a state provided such common law accords with general law.

Here, again, we run into difficulties. In the first place, this proviso would require the members of the commercial community to ascertain, at their peril, what is the "general law" on a given subject, and, assuming that they could ascertain it, whether the applicable state decisional law is or is not in accord with it. Then, too, what would happen if a state's common law should not be in accord with the "general law"? Under the language of the bills, there are two simple tests-the statute, if there is one, or the common law of the state, if there is no statute. This proviso would impose a third, of, it is submitted, the most indefinite nature.

All of this is well illustrated by the torture through which the United States Supreme Court went in connection with accounts receivable. In Salem Trust Company v. Manufacturers Finance Co., ${ }^{40}$ it attempted to lay down some principles of "general law" on the subject of notification as a prerequisite to the perfection of title to assigned accounts. Although, after the decision of Erie Railroad v. Tompkins, ${ }^{41}$ the Salem Trust Company case lost much, if not all, of its force, it survived to the extent of furnishing some justification for the decision in the Vardaman case, which all condemn. Since the concept of "general law" would seem even more elusive than that of "equitable lienor," its incorporation into the limitations of the statute would hardly seem wise, and would again lead us into confusions and uncertainties.

\footnotetext{
so "It is not contended by the authors that there are no equitable liens that could be uscful and satisfactory credit devices in a sound economy." Keeffe, el al., supra note 37 , at I r2.

10264 U. S. 182 (I924).

${ }^{11} 304$ U. S. 64 (1938).
} 
IV

Suggestions for the AMendment of OTher Sections OF THE BANKRUPTCY ACT

In addition, other students of the subject ${ }^{42}$ felt the desirability of amending, largely in the interests of conformity, certain other and more or less related sections of the Act.

A

Attention was called to Section $3 b^{43}$ which treats of the time of the filing of an involuntary petition; specifies that it may be filed within four months after the commission of an act of bankruptcy; and then goes on to provide that, with respect to certain acts of bankruptcy, such period "shall not expire until four months after the date when the transfer or assignment became so far perfected that no bona fide purchaser from the debtor and no creditor could thereafter have acquired any rights in the property so transferred or assigned superior to the rights of the transferee or assignee therein."

It was accordingly pointed out that the elimination of the bona fide purchaser test in Section 6oa should also carry with it a corresponding elimination from Section 3 b. On the other hand, it was felt that while any transfer which is voidable - under Section 6oa should certainly be deemed an act of bankruptcy under Section 3, this does not necessarily lead to the conclusion that an act of bankruptcy, as specified in Section 3, need be restricted, for the purposes of that section, only to those transfers which are preferential and therefore voidable under Section 6oa. In other words, what constitutes an act of bankruptcy for the purposes of the earlier section could be more liberal or more stringent as against debtors than the specification of what constitutes a preferential transfer, voidable, as against a trustee in bankruptcy, under Section 6oa; and there was no compelling reason why the liberality of Section $3 \mathrm{~b}$ should be curtailed, particularly since it is not the present purpose to accomplish a revision at large of the Bankruptcy Act, but rather to ameliorate a specific evil.

\section{B}

The elimination of the reference to "bona fide purchaser" in the fraudulent conveyance section (Section $67 \mathrm{~d}(5))^{44}$ was suggested upon much the same grounds as had been urged with respect to its elimination from Section $3 \mathrm{~b}$. The same reasoning applies to this suggestion. In addition, the underlying object of this comparatively recently enacted fraudulent conveyance section is somewhat different, and, from a bankruptcy standpoint, more restricted than the older preference section.

The National Bankruptcy Conference proposes to attack this problem from a related or different angle. It proposes to eliminate from Section $67 d(5)$ the phrase "and no creditor," for the reason that "a fraudulent transfer can never "become per-

\footnotetext{
"s Notably William B. Cudlip of the Detroit bar.

65 52 STAT. 844,845 (1938), II U. S. C. A. \$21b (1947).

“ 52 Stat. 875,878 (1938), II U. S. C. A. \$ro7d(5) (1947).
} 
fected' against creditors, and, therefore, as to them, the period of limitation of one year or four months, as the case may be, would never begin to run. This, of course, is not intended. [This] proposed amendment, by deleting the reference to creditors, makes the perfection as against a hypothetical bona fide purchaser the only proper test." 45

There is much to be said for this point. In any event, whether the amendment to Section $67 \mathrm{~d}$ (5), as suggested by the National Bankruptcy Conference, is enacted or not, there seems no compelling reason, in order to achieve the objectives of the amendment to Section 60a, to remove from Section $67 \mathrm{~d}(5)$ the reference to a bona fide purchaser presently contained therein.

\section{$\mathrm{V}$}

The Proposal for the Compulsory National Recordation or the Assignment of Accounts Receivable

In May, 1947, the Board of Directors of the National Association of Credit Men endorsed the amendment "provided that the Bankruptcy Act be further amended to invalidate, as against a trustee in bankruptcy, assignments of accounts receivable, unless a valid and effective notice of intention to assign be on file or of record in a federal office," except in instances in which such notice is required to be filed in accordance with the provisions of applicable state law. ${ }^{46}$ It is reported that the proviso was adopted over considerable opposition. It is also reported that the instrumentalities of the New York Association of Credit Men, which is a constituent part of the national group, have declined to go on record in favor of the proposal.

This matter had been raised before on the state level, in connection with the passage by twenty-seven states of accounts-receivable legislation, and also by $\mathrm{Mr}$. Montgomery at a hearing before the New York State Law Revision Commission in September, 1946, which subsequently studied the subject and rejected the proposal.

On the national level, it had also been brought before the National Bankruptcy Conference at its meeting in Atlantic City in October, 1946, and was there referred to a special committee, consisting of Professor MacLachlan of the Harvard Law School, as Chairman; Mr. Richard S. Douglas of Cleveland; Mr. Delos J. Needham of Washington; Mr. Harry Zalkin of New York; Mr. G. W. S. Musgrave of Baltimore (since deceased); and Professor John Hanna of Columbia Law School. So far as is known, this committee has neither considered the matter nor reported, ${ }^{47}$ and

\footnotetext{
${ }^{45}$ Print of the Drafting Committee of the National Bankruptcy Conference dated February, 1948, pages $3 \mathrm{I}-32 \mathrm{~b}$.

"Letter dated September 5, I947, from W. Randolph Montgomery, Counsel to National Association of Credit Men, to Homer J. Livingston, chairman of the American Bar Association's Scction 6oa Committee. The letter added that the NACM could not "acquiesce in the proposed amendment to Section 6oa unless special treatment be given in the Bankruptcy Act to the matter of publicity for accounts reccivable financing."

"In fairness, it should be stated that Professor MacLachlan and Mr. Douglas undoubtedly favor the proposal, and that Professor Hanna and Mr. Needham oppose it. The views of the remaining members of the committee are unknown to the present author.
} 
no action has been taken upon the proposal by the National Bankruptcy Conference itself. However, a section implementing it was contained in a committee print, circulated in February, 1948, by the Drafting Committee of the Conference, and was introduced in the House (H. R. 5834, 8oth Congress, 2nd Session) on March 15, I948, by Representative Hobbs. This bill is in two parts: Section I is essentially the same as H. R. 2412 and S. 826, amending Section 60a; and Section 2 is the national recordation suggestion, which would become a new and added Section 70 i.

It is not within the ambit of this article to enter into extended debate upon the merits of this controversial proposal, which, on its face, singles out for discriminatory treatment one, but by no means the largest, area of secured credit. However, several observations upon it, and particularly upon its being brought forward in connection with and as conditional to the enactment of the amendment to Section 6oa, many not appropriately be made.

\section{A}

It is opposed with virtual unanimity in the financial and commercial world by extenders of credit of all shapes and sizes, as is manifested by the position taken before the subcommittee hearings by the groups enumerated above. That this reaction is not confined to the extenders of secured credit is demonstrated by the unanimous opposition of the banks, ${ }^{48}$ who are equally interested in unsecured

${ }^{48}$ The position of the American Bankers Association is stated as follows in a letter dated May 12, r 948 addressed by its General Counsel, D. J. Needham, to Representative Reed, Chairman of the Bankruptcy Subcommittee of the House (Committee Hearing, Judiciary Committee, Serial No. I9, page 150):

"The American Bankers Association, Washington 5, D. C., May 12, 1948.

Hon. Chauncey W. Rieed,

Old House Office Building, Washington, D. C.

Dear Mr. Reed: Supplementing my conversation with you as of this date I am pleased to advise you that the American Bankers Association favors the enactment of H. R. 2412. The problem involved in H. R. 2412 has been under consideration for many years by the National Bankruptcy Conference and others. A year ago the Conference and others came to what I understood to be a practically unanimous agreement on the language set forth in the bill. Since that time I understand some people have taken some minor exceptions as to the language.

I have followed this problem personally since 1940 or 1941 and in my opinion this bill is now in first-class condition and needs no alterations. The American Bankers Association favors the enactment of this bill.

Regarding H. R. 5834, the American Bankers Assaciation is opposed to the procedure outlined in the bill, particularly regarding the reference to filing notice of assignment of accounts receivable. Some time ago the American Bankers Association approved in principle a recording statute which might be used by the various States provided the States decided it was what they wanted to do. The Association has at no time urged the adoption of the recording statute in the various States but did approve a general statute which of course would be subject to such amendments which any State would want to make. The principle embodied in State recording is entirely different from the problem set forth in H. R. 5834 .

The Association is of the opinion that the Federal Government should not step in and attempt to lay down the law for any State. That is a problem for the States to handle and they should do it by the enactment of their own laws without the interference of the Federal Government.

The chairman of the Federal legislation committee of the American Bankers Association is Mr. C. Francis Cocke, president, First National Exchange Bank, Roanoke, Va. He is cognizant of this legislation and has the authority to advise on these matters with the cooperation of the other officers of the 
credit, and by the factors, who purchase accounts on a non-recourse basis and therefore constitute probably the largest body of unsecured creditors in the country. As above stated, the National Association of Credit Men and the Commercial Law League of America support it-the former with, and the latter without, the Section $60 a$ amendment.

At least so far as their associations constitute their representative spokesmen, the country's practicing lawyers, widely diverse of professional representation and experience-background, have looked with equal disfavor on the proposal.

Four of the five members of the American Bar Association Committee (John Hanna, J. Francis Ireton, Homer J. Livingston, and the present author) are opposed to it. The fifth member, Professor MacLachlan, who favors it in principle, feels that the enactment of the amendment to Section 6oa should not be unduly delayed by controversy-which, it may be observed, is inevitable-on this subject.

The views of these four members of the American Bar Association's Committee, to whom Mr. Montgomery's letter of $5^{\text {th }}$ September $1947,{ }^{49}$ stating the proposal, was addressed, are set forth as follows in its report dated I7th September 1947::00

r. Your Committee is unanimous that, for the reasons stated in its 1946 report, there is a basic and urgent necessity for the amendment of Section 6oa in accordance with the I946 resolutions of the Section and the House of Delegates, whether or not a Federal recording or filing statute is to be ultimately enacted.

2. All but one ${ }^{51}$ of the members of your Committee are also opposed to the enactment of a national recording or filing act for accounts receivable, either by itself or in connection with the proposed amendment to Section 6oa. It would unwarrantedly extend this report to state at length the reasons underlying his majority conclusion. In brief summary, these reasons are:-

(a) Whether or not the assignment of accounts receivable should be subject to a statutory recording or filing requirement is a highly controversial subject which has been hotly debated for at least the past five years. While, like so many other subjects, it has some collateral bearing on Section 6oa, the necessity for the amendment of that Section is an independent matter which should not be delayed or confused by the injection of an issue so highly debatable.

(b) Passing the questions ( $I$ ) of constitutionality, and (2) of the desirability of Federal, as distinguished from state, legislation covering accounts receivable, it is to be noted that even the many states which have enacted legislation on the subject are by no means unanimous in their prescriptions. Fifteen of the enacting states, including the larger

Association. This letter is being filed with you for the record at the request of Mr. Cocke. We will appreciate it if you will be good enough to put this in the record at your convenience.

\section{Sincerely yours,}

D. J. Needham, General Counscl."

${ }^{10}$ See note 46 supra.

${ }^{50}$ Of course, the quoted portion of the Committee's report does not contain any footnotes. They aave been inserted in the text for reference purposes.

${ }^{52}$ Professor James A. MacLachlan. 
commercial ones, have flatly rejected any recording or filing requirements. These states are:

Arkansas $^{52}$
Connecticut $^{53}$
Illinois $^{54}$
Indiana $^{55}$
Maine
56

Maryland ${ }^{57}$
Massachusetts
Michigan
Minnesota $^{60}$
New Hampshire

Oregon $^{62}$
Rhode Island
South Dakota
Virginia $^{65}$
Wisconsin
66

Several additional states have rejected the idea. Among them is New York, whose Law Revision Commission, after an exhaustive study and the hearing of all interests, declined to adopt it. ${ }^{67}$

A minority of twelve states have adopted it. These states are:

\begin{tabular}{|c|c|c|}
\hline California ${ }^{68}$ & Missouri ${ }^{72}$ & South Carolinat6 \\
\hline Colorado $^{69}$ & North Carolina ${ }^{73}$ & Texas 77 \\
\hline Florida 70 & Ohio 74 & Utah78 \\
\hline Idaho 71 & Oklahoma $^{75}$ & Washington 79 \\
\hline
\end{tabular}

Two additional states, Pennsylvania ${ }^{80}$ and Georgia, ${ }^{81}$ have, at least inferentially, rejected it by enacting a book-marking requirement.

These differences are, of course, due to differing conceptions of local economic needs, and represent the considered practical judgment of the respective business communities involved. To say the least, it is debatable whether local desires on this subject should be overridden, and it certainly should not be done as an appendix to a necessary remediation of the National Bankruptcy Act, which covers a multitude of business activities other than accounts receivable. In any event, the proposed amendment to Section 60a, as heretofore approved by the Section, requires compliance with applicable state recording or filing acts, if any, as suggested at the end of the second paragraph of Mr. Montgomery's letter.

${ }^{62}$ ARK. Dic. Stat. $\$ 1$, p. 172 (Supp. 1947).

${ }^{89}$ Conn. Pub. Acts 1947, No. 305, \$1282i.

8 ILL. REV. STAT. C. I2I 1/2, $\$ 220-222$ (1947).

Es INd. ANN. Stat. \$Ig.2102 (Burns I945).

${ }^{50}$ Me. Laws 1945, c. 100, pp. 140-141.

${ }^{87}$ Mo. ANn. Code LAws art. 8, SIA (Supp. 1943).

"Mass. Ann. Laws C. I07A, \$2 (1946).

${ }^{80}$ Mich. Pub. \& Loc. Acts 1945, No. 309, $\$ 6$.

- Minn. Stat. \$521.02 (Henderson 1945).

,12 N. H. Laws 1945, c. 19, \$2.

${ }^{02}$ ORE. CoMp. LAwS ANN. \$62A-tor (Supp. 1944-r947).

${ }^{63}$ R. I. Acts \& Resolves 1943, c. 1345, p. 196.

' S. D. Sess. Laws 1945, c. 213, p. 220.

ob VA. Code ANn. $\$ 5767$ (a) (Cum. Supp. I946).

60 WIS. Stat. \$241.28 (I945).

${ }^{67}$ Legislative Document No. 65K, December 5, I946, p. 6.

${ }^{88}$ CAL. CIv. Code $\$ 3022$ (Supp. 1947).

${ }^{00}$ Colo. Sess. Laws 1947, c. 120, $\S \S x-9$.

${ }^{70}$ Fla. StAT. ANN. \$\$688.or-688.06 (Supp. I947).

71 Idaho Sess. Laws I945, c. I72, $\$ \$ I-7$.

${ }^{72}$ Mo. Rev. Stat. ANn. c. 18, \$\$3347.1-3347.6 (1939).

${ }^{73}$ N. C. Gen. Stat. Ans. $\$ \$ 44.77-44.85$ (Supp. 1945).

74 OHо CODE ANN. \$\$8509-3-8509-6 (Cum. Supp. 1945).

${ }^{7 \tau}$ Okla. Sess. Laws 1947, c. 5a, \$\$r-7.

${ }^{70} \mathrm{~S}$. C. Acts 1946 , No. 433 , p. 1324 et seq.

${ }^{77}$ Tex. Stat. Rev. Crv. ANN. tit. IIA, art. 260-26x, \$\$1-8 (1917).

${ }^{88}$ UTAF CODE ANN. \$\$81B-0-r-81B-0-6 (Supp. 1947).

${ }^{70}$ Wash. Laws 1947, a $8, \$ \$ 1-12$.

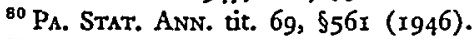

${ }^{81}$ Geo. Laws 1943, No. 178, \$85-1803. 
(c) From a purely doctrinal standpoint, there is little, if any, weight to the argument that since recording or filing is required with respect to chattel mortgages, conditional sales, and trust receipts, the same prescription should be enacted with respect to accounts receivable. The former type of transaction deals with tangibles, in respect of which, as Justice Brandeis pointed out in Benedict v. Ratner, 82 deception is possible because of the reliance that can justifiably be placed upon ostensible ownership arising out of the retention of physical possession, whereas accounts receivable, being intangible, are not susceptible of physical possession.

(d) Unless one is prepared to require publicity for the extension of all types of credit, secured or unsecured, there seems no more reason to single out credit accommodation on the security of accounts receivable than for the discount of notes or any other type of ordinary banking accommodation.

(e) Passing all doctrinal features, the basic practical objection to the imposition of a recording or filing requirement comes chiefly from the small business men, who are most in need of this type of financing; who are not highly organized; and whose interests are, therefore, all too apt to be overlooked in the welter of dispute that exists on this subject. We can put our views no better than did the Law Revision Commission of the State of New York in the last paragraph of its recommendation to the Legislature on 5 December r946:

"In the view of the Commission, a recording or public notice requirement for assignments of accounts receivable has disadvantages which outweigh its advantages. The rapid collection of assigned accounts and substitution of new accounts as security precludes any specification of particular accounts as subject matter in the recording of assignments, and thus any recording or public notice would operate as notice of the assignor's practice of assigning his accounts, rather than as a notice of lien on particular assets. The practice has, in the past, been regarded as indicative of financial distress, and a public notice that accounts are being assigned might frequently give to the assignor's customers and employees (who do not ordinarily have other credit information) an erroneous and unfavorable impression of the assignor's financial position. Creditors and prospective creditors, on the other hand, who do have other and more reliable sources of credit information, would not derive sufficient benefit from a public notice requirement to justify its enactment, for their protection, in view of the hardship to assignors which would result. In the future, when the practice of borrowing upon the security of accounts receivable has become more widespread and the tendency to regard it as an indication of financial difficulty has been overcome, the Commission may resume study of the topic and may present recommendations for legislation.

"Submitted herewith is the study made under the direction of the Commission."8s

After this paragraph, there follows a $300-p a g e$ study, embracing a historical treatment

${ }^{82} 268$ U. S. 353 (r925).

${ }^{88}$ Among those appearing at the hearing before the Law Revision Commission was Professor Karl N. Llewellyn of the Columbia Law School, a keen student of the law of security generally and accounts receivable specifically, and one of the chief Reporters for the American Law Institute and the Conference of the Commissioners on Uniform State Laws on a number of commercial subjects. Although not agreeing with all of the views expressed by the present author at that hearing, Professor Llewellyn observed that, next to cash, accounts receivable are the most liquid and desirable lending assets, concluding his observations as follows: "The point I wish to make is this, that the accounts receivable field is, as Mr. Kelsey (then Chairman of the Committee on Uniform State Laws of the Association of the Bar of the City of New York) said, expanding in proportions which are hard to believe-very properly, in my opinion." This observation of as informed and impartial a student as Professor Llewcllyn emphasizes the necessity of amending Section $60 \mathrm{a}$ so as to lift from accounts receivable finance the burdening cloud that has been pressed upon it by the ruling in the Klauder case. 
of the subject, an analysis of the statute and decisional law in all of the states and in a number of foreign countries, and the minutes of the hearing before the Commission.

B

At the I947 annual convention of the American Bar Association, the Section of Corporation, Banking and Mercantile Law referred the matter for further study to its Committee on Bankruptcy, chairmanned by Frank C. Olive of Indianapolis, and its Special Committee on the Revision of Section 60a. As a result of the investigation and consideration given to the matter by both committees, acting independently, the Council of the Section, at its meeting of May I7, I948, adopted the following resolution:

The Council considered the provisions of H. R. 5834, which consists of two essential parts:-(a) the provisions of H. R. $24^{\mathrm{I} 2}$ to amend Section $60 \mathrm{a}$ of the Bankruptcy Act, and (b) a new proposed Section 7oi, providing for the national recordation of the assignment of accounts receivable, in order to validate them as against a trustee in bankruptcy. This latter proposal has heretofore been brought before the Council, and the considerations in its favor and against it were respectively contained (a) in Mr. Montgomery's letters

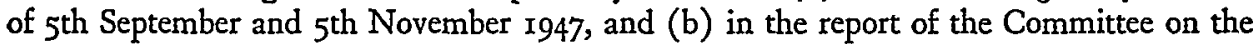
Revision of Section 6oa of the Bankruptcy Act to the Section of I7th September I947; the memorandum of four of the five members of that Committee, dated rgth December I947; and their supplemental statement, dated 5 May r948, submitted to the Subcommittee on Bankruptcy of the Judiciary Committee of the House of Representatives. All of the foregoing have been transmitted to the members of the Council, and have received their consideration.

After discussion, the following preambles and resolutions were, on motion made by Mr. Teiser, and seconded by Mr. Kearns, adopted:

WHEREAS, the proposal for the national recordation of the assignment of accounts receivable would restrict the flow of credit, especially to small business, and is, therefore, particularly undesirable at a time when the channels of credit should be kept free; and

WHEREAS, it is broadly opposed in the commercial and financial communities, and by many groups, representing divers and competitive interests; and

WHEREAS, the proposal has been rejected on the state level by 15 states (including most of the larger commercial ones); has been adopted by I2 of them; and therefore is contrary to the considered public policy of the majority of the states which have enacted statutes on the subject; and

WHEREAS, a proper regard for states' rights requires that the public policy of the states on a subject of this nature be respected; and

WHEREAS, after study and the holding of a public hearing, it has also been rejected by the Law Revision Commission of the State of New York; and

WHEREAS, it would not accomplish the purpose of its enactment, because any potential creditor seeking the benefits claimed for it would need to know the boundaries of all judicial districts and the divisions thereof in the entire United States, and, in many cases, would be compelled to travel long distances in order to reach the recording offices prescribed by the bill; and

WHEREAS, there is urgent need for the enactment of H. R. 24r2, as respectfully recommended to the Congress of the United States by the resolutions of the Section, of October 28, 1946, and the House of Delegates of this Association, of October 30, 1946, 
NOW, THEREFORE, BE IT

RESOLVED:

that the Council disapprove the principle of the required national recordation of the assignment of accounts receivable, either as embodied in H. R. $5^{834}$ in conjunction with the amendment of Section 6oa of the Bankruptcy Act, or independently.

At the 1948 Convention of the American Bar Association in Seattle, held on September 6-9, 1948 , the essence of this resolution was, after discussion and for the reasons just above stated, adopted successively by the Section and the House of Delegates. The text of the resolution, as adopted by the House of Delegates, is as follows:

\section{RESOLVED:}

That the American Bar Association disapproves H.R. 5834, providing for national recordation of the assignment of accounts receivable.

The proposal has also been disapproved by the Chicago Bar Association and the Bankruptcy Committee of the Association of the Bar of the City of New York, and, so far as is known, is not favored by any legal group. In the field of writers, it is opposed by the authors of the "Sick Sixty"84 article, and (at least for enactment at the present time) by Professor Martin. ${ }^{85}$ It is favored by Professor Moore ${ }^{80}$ and by Professor MacLachlan, although, as the present author understands the latter's position, not as a condition to the amendment of Section 60a.

\section{C}

The proposal covers only one area in the broad field of secured credit. Those who borrow and lend on the security of trust receipts, conditional-sales agreements, chattel-mortgages and conditional-sales agreements-areas at least as important and larger in individual (not to mention aggregate) extent-are equally entitled to present relief from the confusions of Section 6oa. They should not be compelled to continue to conduct business with lawyers at their elbows, particularly when those lawyers themselves, in the present state of the law, cannot give them the essential answers.

It is, of course, apparent that the author of this article, and the many who are of like mind with him, are opposed to compulsory national recordation in principle; but, if its merits outweigh its disadvantages, it should be able to stand on its own feet. It seems hardly fair to impose its enactment as a condition to the passage of the amendment to the preference section, which is, by almost universal agreement, so badly needed in the interests of all. On the last mentioned point, to paraphrase Justice Holmes, five years of confusion and uncertainty are enough.

\footnotetext{
${ }^{84}$ In a footnote at the conclusion of their article the authors say: "Many other suggestions for amendment to Section 60 were tested, ranging all the way from retention of the present Section 60 with specific exceptions for named security devices, to a suggestion for a statute detailing specifically each security device with federal recordation provided for perfection. These, likewise, werc found to be sick and ultimately discarded." Keeffe, et al., supra note 37 , at II3 n.

${ }_{48}^{85}$ Col. L. REv. 83-86 (1948).

${ }^{80} 57$ YALE L. J. 683, 696 (1948).
} 